\title{
Old English verbs of prohibition. Grammatical behaviour and class membership 1
}

\author{
Ana Elvira Ojanguren López \\ University of La Rioja
}

The aim of this article is to determine if the Old English verbs bewerian, forbēodan, foresacan, forwiernan, stīeran and tōcwepān constitute a unified class of prohibition. The theoretical model is provided by the framework of verb classes and alternations, as well as by Role and Reference Grammar. Class membership requires not only similar meaning components but also shared grammatical behaviour. While bewerian, forbeodan and forwyrnan are found in three syntactic configurations, and in the Nominalisation and Undergoer alternations, foresacan, stīeran and töcwepān occur in one syntactic configuration only and do not take part in these alternations. The main conclusion of this article is that these verbs do not show a similar grammatical behaviour and, therefore, cannot be said to represent a consistent verbal class.

Keywords: Old English; verb classes; alternations; Role and Reference Grammar

\section{Introduction}

The aim of this article is to analyse the Old English verbs of prohibition bewerian, forbēodan, foresacan, forwiernan, stīeran and tōcwepān as to class membership. A Thesaurus of Old English (TOE, Roberts \& Kay 2000) classifies

\footnotetext{
1 The research presented in this article has been funded through the grant FFI2014-59110-P, which is gratefully acknowledged. I would like to thank Javier Martín Arista for his remarks and comments on earlier versions of this paper. In particular, the description of the Undergoer alternation as raising in Section 4 and the theoretical and descriptive limits of the analysis discussed in Section 6 were pointed out by Martín Arista (personal communication). The usual disclaimers apply.
}

Ana Elvira Ojanguren López, Selim24 (2019): 1-28.

ISSN 1132-631X / DOI: https://doi.org/10.17811/selim.24.2019.1-28 
these verbs under the label of verb of prohibition because they share meaning components related to prohibiting, hindering or preventing that something is the case. With an alternative approach, the analysis carried out in this article is based on the idea that the class membership of verbs depends not only on meaning components but also on grammatical behaviour. This theoretical position, which has been held by Levin (1993) among others, is adopted in this research together with the descriptive and explanatory concepts of Role and Reference Grammar (RRG, Van Valin \& LaPolla 1997), which provides a suitable framework for determining whether or not the verbs at stake share their grammatical behaviour.

The article is organised as follows. Section 2 presents two approaches to verb classes, on the basis of syntactic behaviour and semantic roles. Section 3 reviews previous work on the verbal classes of Old English, with special emphasis on verbs of speech and related meanings. Section 4 describes the method of analysis, including the data sources, the steps of analysis and the application of the theoretical framework. Section 5 deals with the grammatical behaviour of the verbs of prohibition, while keeping an eye on the meaning components that have been identified through comparison with Present-day English. To conclude, Section 6 discusses the results and Section 7 summarises the main findings of the article.

\section{Two approaches to verb classes}

In this section, two approaches to the building of verb classes are reviewed: verb classes based on syntactic behaviour (Levin's framework of verb classes and alternations) and verb classes formed from semantic criteria expressed as thematic roles (Role and Reference Grammar).

Levin (1993) lays the foundation of a research programme in the semantic motivation of syntax that focuses on verbs. It consists of two descriptive concepts, namely verbal class and alternation, which are explanatory with respect to each other. While the semantics of a given verb determines the range of expressions with which it is found, the syntactic configurations shared by a set of verbs is a defining criterion for class membership. That is to say, from the perspective of argument realisation, the number and form of the compulsory complements of a verb is restricted by the meaning component of the verb in question, whereas from the perspective of class membership "verbs that fall into classes according to shared behavior would be expected to show 
shared meaning components" (Levin 1993: 5). Verbal classes and alternations are not explicitly defined. The former are syntactically relevant and semantically coherent, whereas the latter affect the diathesis of verbs (Levin 1993: 22). The characteristic properties of verbal classes include argumenttaking properties, participation in diathesis alternations and morphological properties. For instance, grow verbs include develop, evolve, grow, batch and mature (Levin 1993: 174). The properties of this class include the alternations in (1), which are understood as systematic morpho-syntactic contrasts in the realisation of verbal arguments.

(1)

a. Material/Product Alternation (intransitive)

That acorn will grow into an oak tree.

An oak tree will grow from that acorn.

b. Causative/Inchoative alternation

The gardener grew that acorn into an oak tree.

That acorn will grow into an oak tree.

As Levin (1993: 174) remarks, these verbs show an alternation that can be described as the intransitive counterpart of the material/product alternation in which build verbs participate (as in Martha carved a toy out of a piece of wood vs. Martha carved the piece of wood into a toy). Alternations, therefore, do not only constitute a defining property of verb classes but also allow us to make generalisations across verb classes. For example, the body-part possessor ascension alternation (as in Margaret cut Bill's arm vs. Margaret cut Bill on the arm) distinguishes cut, bit and touch, which participate in the alternation, from break, which does not display this alternation.

Differences in verb behaviour can be explained if alternations are sensitive to certain components of the meaning of verbs. For example, touch is "a pure verb of contact", bit is "a verb of contact by motion", cut is "a verb of causing a change of state by moving something into contact with the entity that changes state", and break is a "pure verb of change of state" (Levin 1993: 10). In other words, certain meaning elements can be defined for a given alternation, which ultimately determines which verbs can undergo the alternation and belong to a certain verbal class.

Turning to verb classes formed from semantic criteria expressed as thematic roles, RRG (Foley \& Van Valin 1984, Van Valin \& LaPolla 1997, Van Valin 2005) classifies verbs with respect to the semantic properties necessary for the description of semantic roles, in such a way that verb classes 
can be derived from the assignment of semantic roles to the arguments of the verb. These questions are addressed in more detail in the remainder of this section, which is based on the overview of RRG available from http://linguistics.buffalo.edu/people/faculty/vanvalin/rrg/RRG_overview.pdf. The tables in this section follow, with few modifications, this overview. This section also draws on this overview for the terminology and the definitions of RRG. Some examples have been changed or modified.

In RRG, the semantic representation of the sentence is based on the Aktionsart (internal aspect) class of the verb. The typology of Aktionsart consists of four classes: State, Achievement, Accomplishment and Activity. States and activities are basic types. Achievements are punctual and accomplishments are durative. Van Valin \& LaPolla (1997) also distinguish the Active Accomplishment (telic uses of activity verbs) and the causative version of all Aktionsart classes. Van Valin (2005), additionally, proposes the Semelfactive class, both non-causative and causative, or punctual events. Aktionsart types are defined by means of the set of features shown in Table 1.

Table 1. Aktionsart or internal aspect (Van Valin 2005)

\begin{tabular}{l|l}
\hline STATE [+static], [-dynamic], [-telic], [-punctual] & Leon is a fool \\
\hline ACTIVITY [-static], [+dynamic], [-telic], [-punctual] & The children cried \\
\hline $\begin{array}{l}\text { SEMELFACTIVE [-static], [ } \pm \text { dynamic], [-telic], } \\
\text { [+punctual] }\end{array}$ & The light flashed \\
\hline $\begin{array}{l}\text { ACHIEVEMENT [-static], [-dynamic], [+telic], } \\
\text { [+punctual] }\end{array}$ & The window shattered \\
\hline $\begin{array}{l}\text { ACCOMPLISHMENT [-static], [-dynamic], [+telic], } \\
\text { [-punctual] }\end{array}$ & The snow melted \\
$\begin{array}{l}\text { ACTIVE ACCOMPLISHMENT [-static], [+dynamic], } \\
\text { [+telic], [-punctual] }\end{array}$ & Paul ran to the store \\
\hline
\end{tabular}

Logical structures relate clausal semantics to clausal syntax and viceversa, thus constituting the main device of semantics-syntax and syntax-semantics linking. Table 2 shows Aktionsart types and the corresponding logical structures. The main distinction is drawn between the stative (predicate') and non-stative $\left(\mathbf{d o}^{\prime}\right)$ part of logical structures. The variables $\mathrm{x}, \mathrm{y}$ and $\mathrm{z}$ stand for verbal arguments. The metalinguistic predicates INGR(essive), SEM(e)L(factive), BECOME and CAUSE indicate, respectively, ingressives, semelfactives, accomplishments and causatives. 
Table 2. Aktionsart types and logical structures in RRG

\begin{tabular}{|c|c|}
\hline Aktionsart type & Logical Structure \\
\hline STATE & predicate $^{\prime}(\mathrm{x})$ or $(\mathrm{x}, \mathrm{y})$ \\
\hline ACTIVITY & do $^{\prime}(\mathrm{x}$, [predicate' $(\mathrm{x})$ or $\left.(\mathrm{x}, \mathrm{y})]\right)$ \\
\hline ACHIEVEMENT & $\begin{array}{l}\text { INGR predicate' }(\mathrm{x}) \text { or }(\mathrm{x}, \mathrm{y}) \\
\text { or INGR do' }\left(\mathrm{x},\left[\text { predicate }^{\prime}(\mathrm{x}) \text { or }(\mathrm{x}, \mathrm{y})\right]\right)\end{array}$ \\
\hline SEMELFACTIVE & $\begin{array}{l}\text { SEML predicate' }(\mathrm{x}) \text { or }(\mathrm{x}, \mathrm{y}) \\
\text { or SEML do }\left(\mathrm{x},\left[\operatorname{predicate}^{\prime}(\mathrm{x}) \text { or }(\mathrm{x}, \mathrm{y})\right]\right)\end{array}$ \\
\hline ACCOMPLISHMENT & $\begin{array}{l}\text { BECOME predicate' }(\mathrm{x}) \text { or }(\mathrm{x}, \mathrm{y}) \\
\text { or BECOME do' }(\mathrm{x},[\text { predicate }(\mathrm{x}) \text { or }(\mathrm{x}, \mathrm{y})])\end{array}$ \\
\hline $\begin{array}{l}\text { ACTIVE } \\
\text { ACCOMPLISHMENT }\end{array}$ & $\begin{array}{l}\left.\text { do }^{\prime}(\mathrm{x}, \text { [predicate1' }(\mathrm{x},(\mathrm{y}))]\right) \\
\text { \& BECOME predicate2' }(\mathrm{z}, \mathrm{x}) \text { or }(\mathrm{y})\end{array}$ \\
\hline CAUSATIVE & $\alpha$ CAUSE $\beta$, where $\alpha, \beta$ are LSs of any type \\
\hline
\end{tabular}

The semantic interpretation of verbal arguments in RRG is based on two generalised semantic roles or macroroles called Actor and Undergoer. Macroroles make grammatical generalisations across argumental structures. In a transitive predication, the Actor is the first argument and the Undergoer the second argument of the verb. In an intransitive predication, the only argument can be an Actor or an Undergoer, depending on the semantic properties of the predicate. The number of macroroles that a predicate takes is called macrorole transitivity. This definition is semantic and is intended to distinguish the number of macroroles from the number of syntactic arguments, called syntactic transitivity. The three possibilities of macrorole transitivity are: transitive (2 macroroles), intransitive ( 1 macrorole) and atransitive (0 macroroles). There is no third macrorole available for ditransitives. The third argument is called a non-macrorole direct core argument.

As regards grammatical relations, subject and object are not universal for RRG. Instead, RRG posits the concept of Privileged Syntactic Argument (PSA). In an active construction, the macrorole Actor is linked to PSA if the verb is dynamic, while the Undergoer becomes the PSA with stative verbs. In passive constructions, the macrorole Undergoer enjoys the status of PSA. The other arguments in a clause are core arguments, either direct (without preposition) or oblique (with preposition, or case-marked genitive or dative in inflectional languages like Old English). Some constraints operate. In some languages only macrorole arguments can be linked to PSA, whereas in others, such as Old English, non-macrorole core arguments can be linked to PSA. 
Linking is the correspondence between syntax and semantics, which operates in both ways. The linking between syntax and semantics is governed by the Completeness Constraint, stipulating that all the specified arguments in the semantic representation of a sentence must be realised in the syntax, and conversely that all the expressions in the syntax must be linked to some element in the semantic representation of a sentence, in order to be interpreted. Important elements of linking are verb agreement, case assignment and prepositional government.

The RRG theory of complex sentences is based on two concepts, juncture and nexus, in such a way that the type of unit (juncture) is independent of the type of relation (nexus). Beginning with juncture, it is necessary to make reference to the structure of the clause in RRG. The layered structure of the clause is a hierarchical structure that consists of several semantic layers that are motivated by the scope of operators (grammatical features such as tense, aspect, modality, etc.). The central components of the logical structure of the clause are the Core (a verbal nucleus with its arguments and its argumentadjuncts, as in drink wine and go to the park respectively), the Clause, which is comprised of the Core and the Periphery (as in play chess in the park), and the Sentence, which consists of one or more units of Clause level, as in I read a novel before going to bed. These components, in the RRG view, also represent the fundamental constituents of complex sentences. The unmarked pattern for the construction of complex sentences involves the combination of nuclei with nuclei, cores with cores, clauses with clauses, and sentences with sentences. These are called levels of juncture. Depending on the degree of complexity of the combining units, the types of juncture are nuclear juncture, core juncture, clausal juncture and sentential juncture. Nuclear junctures, for example, are complex constructions made up of multiple nuclei. For example, in John forced open the door, two nuclei, force and open, can be found in a single core. Core junctures comprise two or more cores in a clause, as in I ordered Fred to force the door open. In this type of core juncture, the two cores share a core argument, in this case the participant Fred. A clause juncture can be identified in more complex structures of the type John phoned Mary yesterday and Jim phoned her too. Further differences between the levels of juncture have to do with complementisers (to, from, etc.). Nuclear junctures do not include complementisers, whereas core junctures may require them. As a result, the two nuclei can be adjacent in a nuclear juncture, while they cannot be adjacent in a core juncture. 
The possible syntactic and semantic relations between the units in a juncture, called nexus, include coordination and subordination. Subordination is divided into two subtypes, daughter subordination, when the subordinate clause functions as an argument, as in That she arrived late shocked everyone; and peripheral subordination, when the subordinate clause is a periphery, as in Kim saw Pat after she arrived at the party. Both subtypes of subordination are possible at the clause, core and nuclear levels. For subordination to take place, it is a requirement that clefting and passivisation are possible. Thus, Mary regretted Jobn's losing the race is an instance of subordination because the cleft (It was Jobn's losing the race that Mary regretted) and the passive (For Jobn to lose the race was regretted by Mary) are possible (Van Valin \& LaPolla 1997: 445). To the traditional nexus types of coordination and subordination, RRG adds a third nexus type, called cosubordination, which is dependent coordination. In cosubordination, the dependence is due to the operators, given that the units must share at least one operator at the level of juncture. For example, in Mary sat playing the guitar the operator of imperfect aspect has scope over both nuclei, sat and playing.

\section{Review of previous work}

The Lexematic-Functional approach to Old English verbal classes distinguishes constructions (recurrent associations of form and meaning) and alternations (recurrent contrast of form and meaning). Both constructions and alternations make reference to the semantics of the verbs in question by identifying the Aktionsart (internal aspect) realisations and also refer to the syntax of verbs (including argument realisation, case marking and prepositional government and clausal relations within the complex sentence). For a certain verbal class to be distinguished, as in the framework of verb classes and alternations (Levin 1993), not only the expression of a common meaning but also a certain degree of similar grammatical behaviour are compulsory.

If we concentrate on the specific contributions of the LexematicFunctional approach to Old English verbal classes, several verb classes have been studied, along with their logical structures (formal representation of Aktionsart types), constructions and alternations: verbs of warning (González Orta 2002), verbs of running (Cortés Rodríguez \& Torres Medina 2003), verbs of writing (Cortés Rodríguez \& Martín Díaz 2003), verbs of smell perception and emission (González Orta 2003), verbs of speech (González Orta 2004), 
remember verbs (González Orta 2005), verbs of sound (Cortés Rodríguez \& González Orta 2006), verbs of feeling (C. L. García Pacheco 2013), and verbs of existence (L. M. García Pacheco 2013); as well as some specific constructions, like the resultative (González Orta 2006).

González Orta (2006), in a representative work, proposes a lexical template for the class of verbs of speech. A lexical template is a lexical representation that includes syntactic and semantic information within the same format, based on the logical structures of RRG and semantic decomposition. For example, the resultative construction describes the state achieved as the result of an action (Levin 1993: 101). This construction is instantiated in subconstructions involving verbs of speech. In the case of Old English verbs of speech, each event comprises the subevents in Table 3.

Table 3. Subevents in events of speech (González Orta 2006)

The activities [do' $(\mathrm{y}, \mathrm{z})]$ and [NOT do' $(\mathrm{y}, \mathrm{z})]$ regarding command, ask and forbid verbs

The state [want' $(\mathrm{y}, \mathrm{z})]$ with persuade verbs

The accomplishments [BECOME believe' (y, z)], [BECOME think.again.about something (a).be.in.mind.from.before' (y, z)] and [BECOME know' $(y, z)]$ concerning persuade, remind and tell verbs, respectively

In the first subevents of the constructional templates in Table 4, the external variable $(\mathrm{x})$ acts as effector initiating an action (do') by using (use') verbal means (voice/words), in such a way that, focusing on verbs command and ask verbs, this effector causes (CAUSE) someone to do or not to do something.

Table 4. The resultative construction: constructional templates with verbs of speech (González Orta 2006)

Command verbs

[do' (x, [use' ( $x$, voice/words)] CAUSE [do' (x, [express.instructions.(a).to.(b). in.language. $\left.\left.\left.(c)^{\prime}(x, y)\right]\right)\right]$ CAUSE $\left[d^{\prime}(y, z)\right]$, where $y=b, z=a$.

Ask verbs

[do' (x, [use' (x, voice/words)] CAUSE [do' (x, [express.requests.(a).to.(b).

in.language. $\left.\left.\left.(c)^{\prime}(x, y)\right]\right)\right]$ CAUSE $\left[d o^{\prime}(y, z)\right]$, where $y=b, z=a$. 
As can be seen in these tables, the template motivates a set of constructionbased templates corresponding to the related constructions.

\section{Method. The semantics and syntax of verbs of prohibition}

In this section, the method of research is described, including the data sources, the steps of analysis and the application of the theoretical framework as well as the synthesis presented in the previous sections to the verbs under analysis.

As regards the data sources, the inventory of verbs of prohibition has been retrieved from $A$ Thesaurus of Old English (TOE). The verbs beginning with the letters A-H have been consulted on The Dictionary of Old English (DOE). All the citations corresponding to the meaning under analysis have been selected. For the verbs beginning with the letters I-Y, the citations in the Bosworth-Toller Dictionary have been extracted.

This research takes the following steps of analysis: firstly, it describes the semantics and the grammatical behaviour of verbs of prohibition in Presentday English; in the second place, it analyses the realisation of arguments and the structure of the clause with Old English verbs of prohibition; thirdly, it identifies the alternations found with verbs of prohibition; and, finally, it assesses the consistency of the set of verbs of prohibition as a verbal class in Old English.

With respect to the semantics of prohibition in Present-day English, forbidding is a speech act. It has the illocutionary force of a negative imperative of the form Don't do X. Semantically, the first argument is a prototypical agent: a volitional initiator with authority over the addressee. The addressee undergoes a change of state whereby they are no longer allowed to do something. This is typically an activity controlled by the addressee. The change of state may or may not be punctual, from being allowed to not being allowed to do something.

Verbs of prohibition do not presuppose that the forbidden action does not take place. In this respect, verbs of prohibition are substantially different from verbs of prevention, which presuppose that the action was not accomplished (as in The ministers prevented the president from resigning). Prevent verbs, unlike verbs of prohibition, take the complementiser from. For this reason, the logical structure posited for forbid verbs by González Orta (2006), a Causative 
Active Accomplishment, is not adopted in this research. The Causative Accomplishment is preferred to indicate that a process has taken place whereby someone is no longer allowed to do something. This process may be durative but its logical end is that someone is forbidden to do something. The metapredicate BECOME marks the culmination of the process. The logical structures of verbs of prohibition such as forbid and verbs of prevention like prevent are presented in Table 5.

Table 5. The logical structure of forbid and prevent

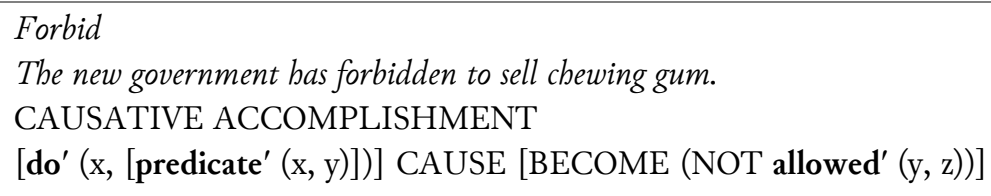

The new government bas forbidden to sell chewing gum.

CAUSATIVE ACCOMPLISHMENT

[do' (x, [predicate' $(x, y)])]$ CAUSE [BECOME (NOT allowed' (y, z))]

\author{
Prevent \\ I cannot prevent you from doing so. \\ CAUSATIVE ACTIVITY \\ [do' (x, [predicate' $(\mathrm{x}, \mathrm{y})])]$ CAUSE [NOT do' $(\mathrm{y}, \mathrm{z})]$
}

The lexical representation of forbid in Table 5 is a simplified version of the logical structure of promise, which states that the speaker expresses an obligation to someone to do the action denoted by the logical structure filling the second argument of obligated' (Van Valin \& LaPolla 1997: 551). This lexical representation is consistent with the logical structure posited for transfer of possession (Van Valin \& LaPolla 1997: 583).

Syntactically, verbs of prohibition are found in the Nominalisation alternation, which involves a simplex clause with an argument (typically, the first argument) that usually entails a predication with its participants expressed as modifiers; and a complex sentence in which the linked clause expresses the prohibition with a non-finite verb that takes a direct argument of its own, as in The consumption of alcohol is forbidden vs. It is forbidden to consume alcobol. The alternation between the that-clause and the infinitive, which holds in Old English, is archaic in Present-day English and is found only in expressions like Heaven forbid that he should go there. 
Verbs of prohibition are also found in the Undergoer alternation, which can be described as a result of raising from Actor in the linked clause to Undergoer in the matrix clause, as in The king forbad that borses should be sold vs. The king forbad to sell horses. In a clausal subordination juncture like The king forbad that horses should be sold, the linked clause that horses should be sold is assigned the macrorole Undergoer, whereas in the core coordination juncture The king forbad to sell horses, the linked core to sell borses does not receive the macrorole Undergoer. The reason is that the clausal subordination juncture can be turned into a passive with the Undergoer as target, thus Selling horses was forbidden by the king, while no such passive is possible on the basis of the core coordination juncture. If there is an explicit patient of prohibition, as in The king forbad that farmers sold horses vs. The king forbad farmers to sell horses, competition arises to get Undergoer status between the patient of prohibition (farmers) and the object of prohibition (to sell horses). In The king forbad farmers to sell horses the patient of prohibition is assigned Undergoer, while in The king forbad that farmers sold borses it is the object of prohibition that gets the macrorole Undergoer. As has been remarked above, Undergoer competition is ultimately a matter of raising from Actor in the linked clause to Undergoer in the matrix clause. Morphologically, this involves a shift from nominative to dative case, in such a way that the accusative is related to the Nominalisation alternation and the dative to the Undergoer alternation.

To conclude this section, the criteria for analysing the grammatical behaviour of verbs of prohibition are listed. They are based on the semantics and syntax of these verbs, as presented in this section, as well as on the theoretical model and the previous research reviewed above. The criteria are the following: nexus and juncture type; complementiser; finite vs. non-finite form of the dependent verb; Aktionsart type; semantic valence (transitivity of macrorole); syntactic valence (obligatory arguments and argument-adjuncts); omitted arguments (in parallel or coordinated constructions); unspecified arguments (second or third argument); Actor vs. Undergoer PSA; morphological case of arguments; prepositional government in argumentadjuncts. The criterion of voice is not considered because it is redundant with respect to Actor vs. Undergoer PSA. The relative order of arguments may be taken into account if recurrent alignments turn up. 


\section{The grammatical behaviour of Old English verbs of prohibition}

This section analyses the grammatical behaviour of the Old English verbs of prohibition bewerian, forbēodan, foresacan, forwiernan, stīeran and tōcwepan in order to determine their class membership. The approach is qualitative and aims at the different argument realisations found in the data. Notice that in the examples in this section fragments are named as in the DOE.

Bewerian, according to the DOE, means 'to ward off, defend, protect' and, more to the point, 'to hinder, restrain'. This verb is found in the two alternants of the Nominalisation alternation, which, as has been said above, comprises a simplex clause with an argument that can entail a predication, and a complex sentence in which the linked clause expresses the prohibition with a non-finite verb. In example (2), bewerian turns up in a simplex clause that belongs in a coordinate subject construction, in which a non-macrorole argument in the dative case realises the patient of prohibition (bim 'to them') and a direct macrorole argument (Undergoer) case-marked accusative (aghwylc yfel 'every wicked thing') expresses the object.

(2) [HomS 47 21]

Se Halga Gast bie aghwylc god larde, \& bim aghwylc yfel bewerede.

The Holy Spirit taught them every good thing and prohibited them every wicked thing.

The other alternant can contain either a finite or a non-finite verb in the dependent clause, so that the nexus-juncture types are clausal subordination or core coordination. In (3), the linked clause, introduced by the complementiser pat, is assigned the macrorole Undergoer and is linked to PSA.

(3) [Bede 1 16.70.18]

Swelce is eac bewered pet mon bine menge wið his broðorwife, forðon purb pa arran gepeodnesse heo wes geworden his broðor lichoma.

So also it is forbidden that a man weds his brother's wife, for by the previous union she became his brother's body.

Core junctures with coordination nexus that contain bewerian can take a complementiser, such as to in the inflected infinitive to etanne 'to eat' in (4a); or no complementiser at all, as is the case with the uninflected infinitive onwreon 'to uncover' in (4b). 
(4)

a. [Bede 1 16.80.7]

Mid by seo a monig ping bewereð to etanne, swa swa unclane, bweðre in godspelle Dribten cwer...

For while the law prohibits the eating of many things as unclean, in the gospel the Lord said...

b. [Bede 1 16.70.8]

Seo balige a bewereð \& forbeodeð pa scondlicnesse onwreon magsibba.

The holy law prohibits and forbids to uncover the shame of relatives.

Semantically, the object of prohibition does not receive the macrorole Undergoer in simplex clauses, like (2a), and core coordination junctures, like (4a) and (4b), because the patient of prohibition usually gets the Undergoer and the agent of the Causative Accomplishment is the Actor. Then, the Actor argument licenses the nominative case and the Undergoer is case-marked dative. In clausal subordination junctures, the object of prohibition rather than the patient of prohibition is the Undergoer. Given that there is competition for the assignment of this macrorole with bewerian, it can be said that this verb is found in the Undergoer alternation.

The PSA can be linked to the Actor or the Undergoer, so that two passives are possible: on the object and on the patient of prohibition. In (5a) the clausal subordination corresponds to the assignment of PSA to the object of prohibition Undergoer, while in $(5 \mathrm{~b})$ the patient of prohibition Undergoer gets PSA, but is omitted. The argument-adjunct inflected for the dative and governed by the preposition from expresses the object of prohibition.

(5)

a. $\quad$ [Bede 1 16.76.19]

Fulwian ponne pat cennende wiif oðpe pat bearn pat par acenned bið [...] nenige gemete is bewered.

So then, to baptise a woman after childbirth or the new-born child [...]

is in no way prohibited.

b. [Bede 1 16.76.2]

Hwelce rebte mag ponne bewered beon from gife pes halgan fulwibtes.

For what reason may then one be prohibited from the gift of Holy Baptism?

Example (5b) reflects the semantics and syntax of prevent verbs rather than the configuration of verbs of prohibition. Firstly, it does not realise a predicative object of prohibition and presupposes its non-occurrence, unlike verbs of 
prohibition, which do not presuppose that the object of prohibition is not going to be the case. Secondly, it takes the complementiser from 'from' rather than to or pat, as the other examples presented above do.

Finally, with bewerian there is a tendency for the dative core argument expressing the patient of prohibition to be placed after the nominative and before the core, the clause or the direct argument realising the object of prohibition.

Forbeodan is, from the point of view of meaning definition, a typical verb of prohibition. According to the DOE, it means 'to forbid, prohibit; to ban, refuse; to restrain, check, hinder, prevent; to resist, deny'. This verb is found in the Nominalisation alternation because the object can be non-verbal and verbal. This verb appears in simplex clauses with an accusative noun phrase that realises the object, such as elc wiflac 'all cohabitation' in (6a), and in complex sentences like (6b) and (6c). In core coordination instances like (6b), the object of prohibition constitutes a non-macrorole core, thus to donne 'to do' and its arguments. In clausal subordination constructions in the active voice like (6c), the object of prohibition (pat nan man na ma wifa nabbe buton $I$ 'that any man has more than one wife') receives Undergoer. In (6a), (6b) and (6c) the agent of the Causative Accomplishment is case-marked nominative.

(6)

a. [HomU 40 144]

Hig forbudon afre alc wiflac weofodpenum, pat is bisceopum and messepreostum.

They forbade for ever all cohabitation to servers of the altar, that is, bishops and mass-priests.

b. [ThCap 1 10.317.3]

Forpan pe we forbeodað agðer ge geflytu ge plegan ge unnytta word ge gebwylce unnyttnesse in pam balgan stowum to donne.

Therefore, we forbid to do any quarrelling, dancing, vain words or any other follies in that holy place.

c. [LawNorthu 61]

And we forbeodað on Godes forbode, pet nan man na ma wifa nabbe buton I.

And we forbid after God's prohibition, that any man has more than one wife.

The general tendency is for the core coordination to opt for the inflected infinitive, and for the clausal subordination to select a finite form of the verb conjugated for the subjunctive, as is the case with leornode 'learnt' in (7). 
(7) $\quad$ Or 6 31.150.14]

pa was he sona geornfull pat be wolde diegellice pone cristendom onwendan \& forbead openlice pat mon nane faste boc ne leornode.

Then he was soon glad that he would secretly avert the Christian faith and he openly forbade that anyone read the fast book.

This verb is also found in the Undergoer alternation, given that there is competition for the assignment of this macrorole. The tendency is for the subject of prohibition to be realised as a dative both in core coordinations, like $u s$ 'us' in (8a), and in clausal subordinations, as is the case with bim 'them' in (8b).

(8)

a. $\quad[\mathrm{CP}$ 48.369.1]

Eac bie sint to manigenne Jatte bie Jurb biora gedwolan \& Jurb biora

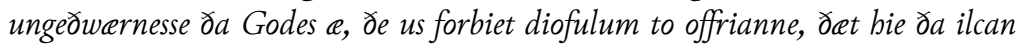
a ne gebwierfen to diofulgielde.

They are also to be admonished with their errors and disagreement over the law of God, which forbids us to sacrifice to devil, that they do not turn the law into an offering to the devil.

b. [CP 32.211.22]

Ne sculon we no bi Jreagean suelce bie bit gedoon habben, ðeab bit gedon sie, ac we sculon bim forbeodan yat bie buru sua ne don.

We should not blame them as if they had done it, although it be done, but at least we must forbid them to do so.

However, the patient of prohibition can be realised as an argument of the matrix clause, thus the dative bim 'him' in (9a), or as an argument of the linked clause, such as the nominative ne kyning ne nan man 'no king and no man' in (9b). Example (9a) also illustrates the realisation of the patient of prohibition as an argument of the linked clause.

(9)

a. [CP 32.211.22]

Ne sculon we no bi Jreagean suelce bie bit gedoon habben, Jeab hit gedon sie, ac we sculon him forbeodan dat bie buru sua ne don, suelce bit donne giet gedon ne sie.

We should not blame them as if they had done it, although it be done, but we must forbid them to do so, as if it were not yet done. 
b. [ChronE 656.93]

ic Uitalianus papa [...] forbede pet ne kyning ne nan man ne baue nan onsting buton pon abbod ane.

I Vitalianus pope [...] forbid, that any king, or any man, have any ingress, but the abbot alone.

The competition for the macrorole Undergoer is also reflected by the fact that both the patient and the object of the prohibition can be duplicated, which guarantees the assignment of Undergoer to the duplicated role and excludes the other. For instance, in (10a) the dative pam blindan 'to the blind' in the matrix clause is co-referential with the nominative be 'he' in the linked clause. In (10b) the accusative bit 'it' in the matrix clause anticipates the linked clause pert bi ne weopon 'that they would not weep'.

(10)

a. [ÆHomM 12 75]

Hi forbudon pam blindan pat he to pam belende ne clypode.

They forbade the blind man to talk to the Saviour.

b. [Alex 40.13]

Ac pa forbead hit se bisceop pat bi ne weopon.

But then the bishop forbade them to weep.

A consequence of the competition for the assignment of Undergoer is the double case marking of the patient of prohibition. It is usually case-marked dative, even in the absence of an accusative noun phrase, as bim 'to him' in (11a), but it can also be inflected for the accusative, as bine 'him' in (11b).

(11)

a. $\quad \mathrm{Mk}$ (WSCp) 9.38

Lareow, sumne we gesawon on pinum naman deofolseocnessa ut adrifende se ne fyligð us, \& we him forbudon.

Teacher, we saw someone casting out demons in your name who does not follow us and we forbade him.

b. [Lk (WSCp) 9.49]

Bebeodend, we gesawon sumne on pinum naman deofolseocnessa ut drifende \& we bine forbudon.

Master, we saw someone casting out devils in your name, and we forbade him. 
With forbeodan, the PSA is linked to the Actor more frequently than to the Undergoer. Instances of PSA Undergoer, nevertheless, include realisations in both simplex clauses like (12a) and complex sentences such as (12b).

(12)

a. [Conf 1.1381$]$

Nis horses flesc forboden peab ðe bi fela magða picgean nelle.

Horse meet is not forbidden although many men will not taste it.

b. [HomU 53 112]

Đonne is eow micel neadpearf pat ge gebeton pa ping pe eow fram Gode forbodene weron.

Because it is a great necessity for you that you make good the things that were forbidden by God to you.

In both (12a) and (12b), passivisation is done on the object of prohibition. When the patient of prohibition is the target of passivisation, the dative case of the corresponding active is preserved in the passive construction. This happens in (13), with the PSA linked to the dative Jøm sacerde 'the priest'.

(13) $[$ CP 18.139.24]

Suiðe rybte was ðam sacerde forboden ðat he his heafod sceare, \& eac ðat he bis feax lete weaxan.

The priest was with good reason forbidden to shave his head or to let his hair grow.

Finally, the patient of prohibition, usually case-marked dative, tends to follow the auxiliary and to precede the lexical verb of the matrix clause, thus, for instance, Jam sacerde 'the priest' in (13). This is the case not only with complex sentences but also with simplex ones, like (11a) and (11b), in which the dative precedes the lexical verb. The existence of counterexamples like (6a) indicates that this represents a tendency rather than a strict rule.

According to the DOE, the verb forsacan primarily means 'to refuse'. It can also be found glossing Latin probibere in sense 'to refuse, prohibit, forbid (someone from an action)'. In (14), the patient and the object of prohibition are omitted because they can be recovered from the context. By analogy with the verbs discussed so far, the simplex clause configuration can be proposed, with the agent of the Active Accomplishment assigned to the macrorole Actor and realised by a noun phrase case-marked nominative; and the patient of 
prohibition assigned to the macrorole Undergoer and realised by a noun phrase inflected for the accusative. The nominative is linked to PSA.

(14) $[\mathrm{MtGl}(\mathrm{Li}) 006300$ (3.13)]

Đa cuom baelend from in to pet he were gefulwad from bim. sodlice foresoc $t$ forbead bine cued ic from ðe rehtra is gefulwia \& yu cuom tcymes to me.

Then the Saviour came to be baptised by him. Indeed, John prevented and prohibited him and said: it is more suitable that I am baptised by you and you come to me.

The DOE entry to forwyrnan defines the meaning of this verb as 'to refuse, deny; to hinder, prevent, restrain, forbid, prohibit'. In simplex clauses, the object of prohibition is case-marked genitive, as in (15a), while the patient of prohibition is inflected for the dative, as in (15b). In (15c), both the object of prohibition and the patient of prohibition are realised, in the genitive and the dative, respectively, thus us 'us' and pees 'of that'.

\section{(15)}

a. [ChrodR 16.17$]$

And gif se eard sy wynes westmbare, sylle man daghwamlice alcum breðer fif punda gewibte wines, gif pa unwedru bis ne forwyrnað.

And if the earth is devoid of wine, one must give daily to each brother five pounds of weighted wine, if the bad weather does not prevent it.

b. [ÆCHom II, 11 103.376]

Ac se balga wer him forwyrnde.

But the holy man restrained him.

c. [ÆCHom II, 40 302.116]

ponne forwyrnð se mildheorta God us pes ðe we ungesceadwislice biddað.

Then the mildhearted God restrains us from that which we foolishly beseech.

Even though the object of prohibition in (15a) and (15c) entails a predication, the semantics and syntax of these clauses corresponds to a prevent verb rather than to a verb of prohibition. As has been remarked above, prevent verbs presuppose that the object of prohibition does not take place, whereas with verbs of prohibition such a presupposition does not hold. Nevertheless, the verb can be found in the Nominalisation alternation, as it takes both noun phrases and verbal clauses that realise the object of prohibition.

In complex sentences, this verb appears in core coordination and clausal subordination junctures. In core coordination junctures, the agent of the 
Active Accomplishment is assigned Actor, thus deges leobt 'daylight' in (16a), and the patient of prohibition gets Undergoer, as gehwylcne 'anyone' in (16a). In this example, the object of prohibition is realised as a non-macrorole core, introduced by the complementiser to and with the verb in the inflected infinitive, to gefremmenne paet pat seo nibt gebafad 'to do what the night allows'. Although the patient of prohibition is case-marked accusative in (16a), the tendency is for the patient of prohibition to license the dative case, as it happens in (16b).

(16)

a. [ÆCHom I, 39 522.70]

Swa swa dages leoht forwyrnð gehwylcne to gefremmenne. paet pat seo nibt gepafað.

As the light of day prohibits anyone to do what the night allows.

b. [ÆLS (Auguries) 248]

God us ne nyt swa peab pat we god don sceolon, ne eac us ne forwyrnð yfel to wyrcenne, forðan be be us forgeaf agenne cyre.

Neither does he prohibit us to do evil, because he gave us free will.

In clausal subordination junctures, the linked clause is introduced by the complementiser pat and the verb is conjugated for the subjunctive. The linked clause is assigned Undergoer, in the absence of a dative-marked noun phrase that expresses the patient of prohibition in the matrix clause. Instead, the patient of prohibition is realised as the Actor of the linked clause. This can be seen in example (17) with respect to bit... bit.

(17) Bo 41.144.26

Nat be bit no forðype he wille pat bit geweorðe, ac forðy pe be wile forwernan pat bit ne geweorde.

He does not know it because he wishes that it happens, but because he would like to forbid that it happens.

As in Old English in general, two negations apply simultaneously in example (17). The negation in the matrix clause is lexical and can be attributed to the representation of verbs of prohibition, whose logical structure contains a negation metapredicate, thus do' (x, [predicate' $(\mathrm{x}, \mathrm{y})$ ]) CAUSE [BECOME (NOT allowed' $(y, z))]$; the other negation in this example is syntactic, through the negative word ne 'not'. 
When the patient of prohibition is expressed, it precedes the linked clause in the linear order of the sentence. Since the linked clause has to perform a function at sentence level (in RRG terms this is the same as receiving Actor or Undergoer), the object of prohibition has preference for the assignment of Undergoer over the patient of prohibition. This happens in (18).

(18) [ChristC 1503]

pearfum forwyrndon pat bi under eowrum pace mosten in gebugan.

They prohibited that the needy were allowed to dwell under a roof.

When the object of prohibition is case-marked genitive, the patient of prohibition has priority for Undergoer assignment because no passive can be done on the genitive in Old English. Nevertheless, this verb can be said to participate in the Undergoer alternation. If the patient of prohibition gets Undergoer, the object of prohibition is realised as a non-macrorole core in a core coordination juncture. If the object of prohibition is the Undergoer, the patient of prohibition is not expressed or is marked by the dative case and the position in the order of the sentence, whose juncture is a clausal subordination. Additionally, the patient of prohibition is co-referential with the Actor of the linked clause, thus pearfum...bi in (18).

It is also possible for these verbs to turn up in a case-preserving passive construction such as (19). The dative case of the corresponding active, marking the patient of prohibition, is kept in the passive construction.

(19) [ÆCHom I, 19 331.180]

\& deofol us wile ofslean gif he mot. ac him bið forwyrned purb Godes gescyldnysse.

And the devil would destroy us if he could but he is restrained by God's protection.

This syntactic configuration corresponds to the assignment of the Undergoer to the patient of prohibition, in such a way that the Undergoer then is linked to PSA. The object of prohibition is not realised because it is recoverable from the immediate context and, perhaps, because the competition for Undergoer leaves only a non-macrorole constituent for the realisation of this participant. Finally, the patient of prohibition tends to occupy the pre-verbal position, not only in passives with dative PSA like (19), but also in actives like (18). This also applies to simplex clauses like (15b) and (15c). 
According to the Bosworth-Toller entry to stieran, this verb means 'to steer; to restrain; to reprove; to punish; to prohibit', so that the meaning of prohibition is not central to this verb. When this verb conveys the meaning 'to prohibit', it only appears in simplex clauses. The verb, therefore, cannot be found in the Nominalisation alternation. The patient of prohibition can appear in the genitive, as bis 'him' in (20a) and in the dative, thus Je ungewittigum 'the foolish' in (20b). When the object of prohibition and the patient of prohibition are realised, the former is inflected for the genitive and the latter for the dative, as gielpes 'of arrogance' and monna cynne 'mankind' in (20c). Example (20d) is reflexive, so that the Actor and the Undergoer are co-referential. Given that the patient of prohibition, which is assigned Undergoer, is case-marked dative, the object of prohibition is necessarily realised as a prepositional phrase introduced by fram 'from', a preposition frequently found with prevent verbs.

(20)

a. [Swt. 33, 10]

Iacobus bis stirde.

Jacob restrained him.

b. [Homl. Th. ii. 532, 11-15]

Wel dep se ðe ungewittigum styrb mid swinglum, gif he mid wordum ne meg.

Well does he who restrains the foolish with whipping if he cannot do so with words.

c. [Exon. Th. 299, 20]

He missenlice monna cynne gielpes styreb.

$\mathrm{He}$ in various ways restrains mankind of arrogance.

d. [Homl. Skt. i. 17, 22]

Gif be bim sylfum styrb fram eallum stuntnyssum.

If he refrains himself from all stupidities.

As can be seen in these examples (taken from Bosworth-Toller, like (21)), there is no competition for the assignment of Undergoer between the patient of prohibition and the object of prohibition, the reason being that if the object of prohibition is realised, it is case-marked genitive or appears as a prepositional phrase, neither of which can be linked to PSA or, in standard terminology, become the subject of the corresponding passive in Old English. This is possible on the dative, which, as has been shown above, is preserved in the passivisation of some verbs of prohibition. Furthermore, the impossibility 
of linking a non-macrorole core or a subordinate clause avoids this kind of competition for the assignment of Undergoer.

Still another difference between this verb and the others discussed above has to do with the expression of the instrument. This role does not seem relevant to verbs of prohibition, which tend to code the agent of the Active Accomplishment, the patient of prohibition and the object of prohibition. Example (20b) realises the instrument (mid swinglum 'with whipping'), as is the case with (21), which contains the instrument mid Jare telinge "with his rebuke'.

(21) [Swt. 53, 16]

Se micla creftiga biertende toscyfp and egesiende stierp ofermetta mid yere telinge his bieremonnum.

The great craftsman, who incites encouraging and terrifies, restrains his disciples from prides with his rebuke.

The Bosworth-Toller entry to tō-cwepan defines the meaning of this verb as 'to forbid, prohibit'. It is found in simplex clauses only, in which the object of prohibition (case-marked accusative) is assigned Undergoer, while the agent of the Causative Accomplishment receives Actor and is linked to PSA, as pa wisan lareowas 'the wise teachers' in (22a); or in which the object of prohibition is case-marked nominative, like ordal \& a das 'ordeals and oaths', because, being the Undergoer, it has been linked to PSA in a passive such as (22b).

(22)

a. [Æ HomM 8 (Ass 3) 000200 (5)]

Ac we nellað secgan be pere gesetnysse of ðam gedwylde, pe gedwolmen setton be byre acennednysse, forðan pe byt tocwedon pa wisan lareowas...

But will not speak about the origin of the heresy, which heretics set about her birth, because the wise teachers forbid it...

b. [LawVAtr $003400(18)]$

Ordal \& aðas syndan tocweðen freolsdagum...

Ordeals and oaths are forbidden on feast days...

The patient of prohibition is not realised, either in (22a) or (22b). As for the object of prohibition, it is case-marked accusative in (22a) and, having been linked to PSA, nominative in (22b). These configurations are not compatible with the Nominalisation alternation and with the Undergoer alternation 
because the former requires the complex sentence alternant and the latter depends on the realisation of the patient of prohibition and the object of prohibition.

\section{Discussion}

The analysis presented in the previous section raises two descriptive questions related to the omission of clausal constituents. In the first place, if a subordinate clause and a core are linked to the same matrix clause, it is not possible to determine the type of nexus and juncture of the complex sentence, since the subordinate clause gives rise to clausal subordination with respect to the matrix clause and the non-macrorole core belongs to core coordination. It would, of course, be possible to assume that the matrix clause is omitted before the linked core to gehalgenne ferunga 'to consecrate immediately afterwards' in (23a), in such a way that two different complex sentences were distinguished, one involving clausal subordination and the other core coordination. This is not advisable, however, because when it comes to supplying omitted constituents to verbs that may take a clause or a core as complement, there is no principled way to do so. This is the case, for instance with (23b).

a. $\quad$ [MtMarg (Li) 10.14]

Biscope is forboden pet he onfoe niwecumenum preostum \& to gehalgenne ferunga.

The bishop is forbidden to undertake a rite with new priests and to consecrate them immediately afterwards.

b. [Mk (WSCp) 9.38]

Lareow, sumne we gesawon on pinum naman deofolseocnessa ut adrifende se ne fyligð us, \& we bim forbudon.

Teacher, we saw someone casting out demons in your name who does not follow us and we forbade him.

The second question is also illustrated by (23a). Similar examples have been analysed in the previous section as conveying a case-preserving passive. This has been preferred over supplying a formal subject bit, which is often omitted in Old English, so that the translation into Present-day English would be It is forbidden that the bishop undertakes... / It is forbidden for the bishop to undertake... 
This said, the verbs bewerian, forbeodan, foresacan, forwiernan, stīeran and tōcwepān share some meaning components, as well as certain aspects of their grammatical behaviour. These are verbs with macrorole transitivity 2 with preference for the active voice. They can take a maximum of two direct core arguments (nominative and accusative) and two oblique core arguments (genitive, dative, argument-adjunct), although the maximal number of syntactic arguments is three. However, most of them take two arguments, one in the nominative and the other usually inflected for an oblique case (genitive or dative). In the constituent order of the sentence, these verbs show a clear tendency to insert the dative realising the patient of prohibition in pre-verbal position or between the auxiliary and the lexical verb.

Bewerian, forbeodan and forwyrnan are found in the Nominalisation alternation and the Undergoer alternation. They turn up in simplex clause configuration (Figure 1) as well as in complex sentence configurations, involving either a core coordination with the inflected infinitive (Figure 2) or a dependent clause with the verb in the subjunctive (Figure 3).

Bewerian, forbeodan and forwyrnan can realise the agent of the Active Accomplishment (in the nominative), the object of prohibition (in the simplex clause or as a core in coordination, or as a clause in subordination), and the patient of prohibition (a dative in the matrix clause or a nominative in the linked clause). Some differences arise with respect to these verbs, though. The PSA of bewerian, forbeodan and forwyrnan can be linked to the agent of the Active Accomplishment. On the other hand, while the object of prohibition and the patient of prohibition of forbeodan can achieve PSA status, the patient of prohibition of bewerian cannot be linked to PSA because this verb does not preserve dative in passivisation, and the object of prohibition of forwyrnan cannot get PSA because passives cannot be formed on the genitive. The patient of prohibition is, as a result, the noun phrase around which the complexity of the construction revolves, in terms of co-reference, the assignment of Undergoer, the linking to PSA, the preservation of dative case, and the raising from the linked clause to the matrix clause. In RRG, this kind of PSA is called the pivot of the construction. 


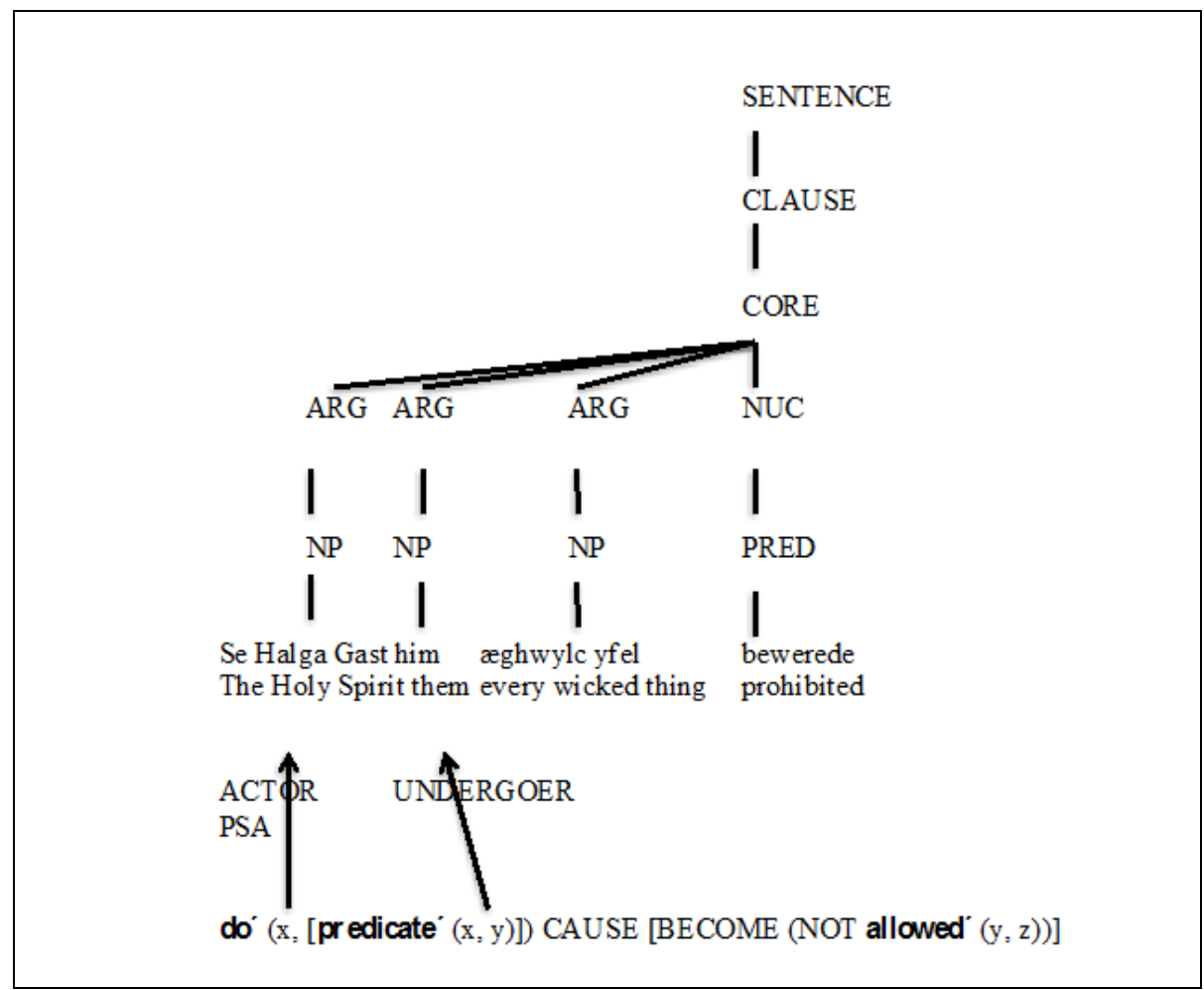

Figure 1. The simplex clause

Foresacan, stīeran and tōcwebān are found neither in the Nominalisation alternation nor in the Undergoer alternation. They appear in simplex clause configurations, in which the agent of the Active Accomplishment is a nominative and, as a general rule, the PSA. The object of prohibition is casemarked accusative (foresacan and tōcwebān) or genitive (stīeran), whereas the patient of prohibition is an accusative (forsacan) or a dative (stīeran).

Therefore, if the requisites for class membership are both meaning components and grammatical behaviour, verbs of prohibition as listed by the TOE can not be said to constitute a verbal class in Old English. 


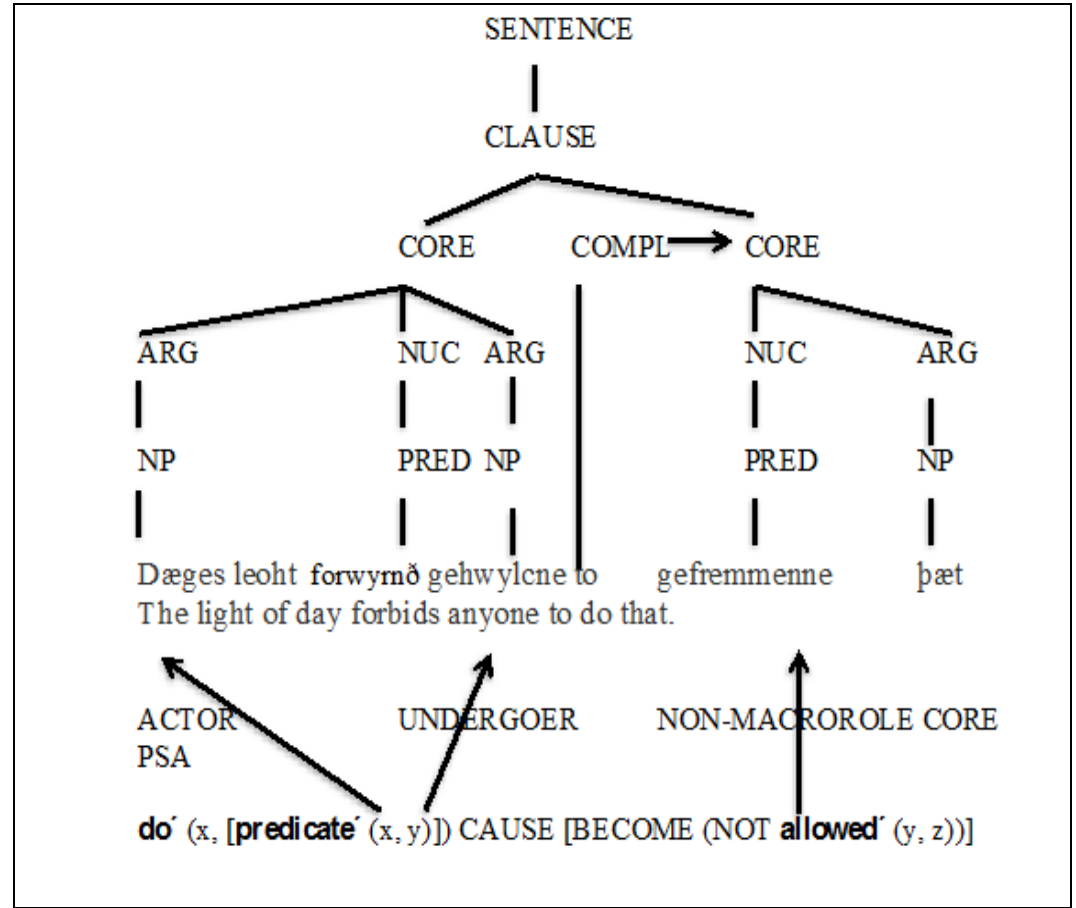

Figure 2. The linked core in coordination

\section{Concluding remarks}

The main conclusion of this article is that the class of verbs of prohibition as gathered by $A$ Thesaurus of Old English is not consistent from a grammatical point of view. Although they share components of meaning, remarkable differences in the grammatical behaviour of these verbs arise related to syntactic configurations and participation in alternations. Bewerian, forbēodan and forwyrnan, which realise the patient of prohibition on a fairly regular basis and whose grammatical complexity revolves around this participant, give rise to a consistent verbal class, not only on the grounds of meaning, but also from the point of view of grammatical behaviour. On the other hand, foresacan, stìeran and tōcwepān are neither found in the three syntactic configurations nor in the two alternations and, furthermore, present divergent meanings. For these reasons, these verbs should be excluded from the class of verbs of prohibition. 


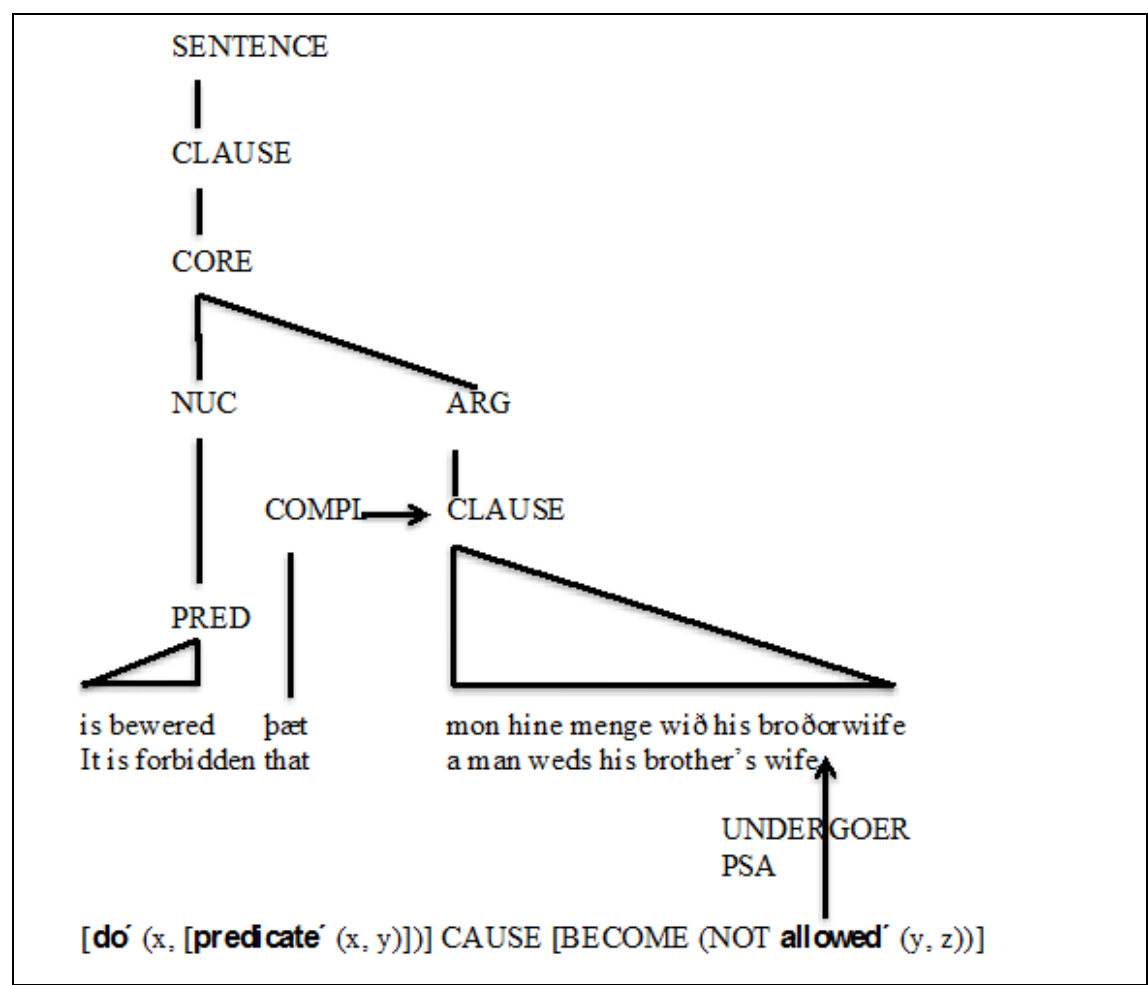

Figure 3. The linked clause in subordination

\section{References}

Bosworth, J. \& T. N. Toller 1973 [1898]: An Anglo-Saxon Dictionary. Oxford, Oxford University Press.

Cortés Rodríguez, F. \& M. González Orta 2006: Anglo-Saxon Verbs of Sound: Semantic Architecture, Lexical Representation and Constructions. Studia Anglica Poznaniensia 42: 249-284.

Cortés Rodríguez, F. \& M. A. Martín Díaz 2003: The Meaning-Syntax Interface of Writing Verbs: Templates, Constructions and Linking Rules within a Lexical Grammar of Old English Verbal Predicates. Revista Canaria de Estudios Ingleses 47: 13-35.

Foley, W. \& R. Van Valin 1984: Functional Syntax and Universal Grammar. Cambridge, Cambridge University Press. 
García Pacheco, C. L. 2013: Los Verbos de Sentimiento en Inglés Antiguo: Arquitectura Léxica e Interfaz Semántica-Gramática. (Ph.D. dissertation.) Universidad de La Laguna.

García Pacheco, L. M. 2013: El Dominio Verbal de la Existencia en Anglosajón. Análisis Semántico-Sintáctico. (Ph.D. dissertation.) Universidad de La Laguna.

González Orta, M. 2002: Linking Syntax and Semantics in Old English Verbs of Warning. Estudios Ingleses de la Universidad Complutense 10: 157-182.

González Orta, M. 2003: The Old English Verbs of Smell Perception and Emission: Analysis of the Interface of their Semantic and Syntactic Representation. SELIM 12: 33-48.

González Orta, M. 2004: Diccionario Sintáctico del Léxico Verbal del Inglés Antiguo: Verbos de Habla. Servicio de Publicaciones, Universidad de La Laguna.

González Orta, M. 2005: The Interrelation of Semantic Structure and Syntactic Variation in Old English Verb Classes: Catalogue of Syntactico-Semantic Constructions. Revista Alicantina de Estudios Ingleses 18: 111-128.

González Orta, M. 2006: The Resultative Construction in Old English: Towards a Semantic Network of Verb Classes. Studia Neopbilologica 78: 123-137.

diPaolo Healey, A. ed. 2016: The Dictionary of Old English in Electronic Form A-H. Toronto: Dictionary of Old English Project, University of Toronto.

diPaolo Healey, A. ed. with J. Price Wilkin \& X. Xiang 2004: The Dictionary of Old English Web Corpus. Toronto, Dictionary of Old English Project, University of Toronto.

Levin, B. 1993: English Verb Classes and Alternations. Chicago, University of Chicago Press.

Roberts, J. \& C. Kay with L. Grundy 2000 [1995]: A Thesaurus of Old English. 2 vols. Amsterdam, Rodopi.

Van Valin, R. 2005: Exploring the Syntax-Semantics Interface. Cambridge, Cambridge University Press.

Van Valin, R. 2014: Some Questions Concerning Accomplishments. Lecture delivered at the 2014 Symposium on Verbs, Clauses and Constructions, held at the University of La Rioja.

Van Valin, R. \& R. LaPolla 1997: Syntax: Structure, Meaning and Function. Cambridge, Cambridge University Press.

Author's address

Departamento de Filologías Modernas

Universidad de La Rioja

C/ San José de Calasanz, 33

26004 Logroño, Spain

e-mail: ana-elvira.ojanguren@unirioja.es

received: 23 January 2018

revised version accepted: 22 May 2018 